\title{
THE MODERN GENRE OF FINNISH MASS SERMON
}

\author{
Päivikki Antola
}

\begin{abstract}
The paper looks into the mass sermon in the Finnish Lutheran Church around the turn of the millennium. The material consists of day services documented by means of participant observation. Day services are nowadays called a mass, if communion is served. A mass sermon can be characterised as persuasive communication encompassing three processes: 1) a process that strengthens a person's worldview; 2) a process that shapes the worldview, or 3 ) a process that changes the worldview. The paper discusses the semantic and functional principles of communication in a mass sermon: familiarisation, emphatic and trustworthy behaviour, self-confidence, personification, principles of opposites and common interest, the authoritarian principle, principles of assigning blame, winning time and building obstacles. From the listener's point of view, the mass sermon answers the question what the listener has to know to be able to interpret the sermon according to his own worldview. I will show that the mass sermon meets the criteria of a religious genre in its origin, form, contents, function, style and structure.
\end{abstract}

Key words: anthropology of communication, audience, mass sermon, non-verbal behaviour, persuasive communication, verbal behaviour of a Finnish priest.

Dear friends, brothers and sisters in Jesus Christ, who is and who shall be, and who shall release us from our sins with His blood; from Him we receive grace, compassion and peace, which is mightier than our understanding and which will protect us in Jesus Christ, our Lord. We have just heard from the altar the second annual gospel text of the second Lent Sunday.

When an apostolic greeting is used at the beginning of a mass sermon, it must not be a disordered collection of bible quotations. This type of a beginning will kill the audience's interest. This can be called the beginning of a non-sermon (concept from Forsberg 2001: 235-243).

The mass sermon (e.g. Suojanen 1978; 1988) is a ritual speech and a personal narrative held in a religious context, in connection with the Holy Communion. This narrative comprises a compulsory textual beginning, which is an apostolic greeting or a chronicate, and after a suggestion or a proposed resolution, it ends in a joint confession.

I shall examine the mass sermon of the Finnish Evangelical-Lutheran Church as a discourse and as persuasive communication (see Baesler 1994; Bettinghaus \& Cody 1994; Stiff 1994; Dillard \& Pfau 2002; Suojanen 2001: 217-234) from the viewpoint of its genre at the beginning of the 21 st century. In this presentation I 
will show that the mass sermon meets the criteria of a religious genre in its origin, form, content, function, style and structure.

The material consists of day services documented by means of participant observation. The project began in 2004, and by the present moment 30 mass sermons have been collected. Day services are nowadays called a mass, if communion is served. The mass sermon aims at religious influence, namely persuasion (persuasion: Dainton 2005; Dillard \& Pfau 2002), and consequently, it is an exercise of power. Power dominance is manifested symbolically through verbal, nonverbal (Klemi 1988; Argyle \& Lefebvre et al. 1974: 125-136; Ekman \& Friesen 1969) and visual communication. A religious use of power is both latent and a conscious manipulation at a certain time, in a certain place and situation. The power of the preacher is the power of a role model, of an expert and of communication.

The Lutheran persuasive rhetoric (persuasion and rhetoric: Stiff 1994) is supported by a written canon, the Holy Bible. The language of persuasion thus portrays the traditional authority structure, which indicates how power is acquired, used and kept with the help of certain core concepts, such as mercy, life, peace, truth, connection, damnation and sin.

The mass sermon as religious persuasion shapes and strengthens a person's worldview, but it rarely changes it (see Lehtonen 1998). Because it is such a powerful tool, the ethics of persuasion (Larson 2001) is also an important consideration. What are the ethical rules of the mass sermon? Can the preacher ignore what kind of an overall influence his or her sermon will have on the listener? We can distinguish between the effect of the sermon's content and the impressiveness of the presentation and the consequences that the sermon has for the listener. A sermon can, for example, motivate the listener to do a good deed for a friend, or an evil deed.

\section{HOW DOES THE SENDER USE PERSUASIVE MEANS IN SERMON COMMUNICATION?}

First, the audience is addressed directly with phrases like hear me friends; dear listeners; you friend; we, the sceptics, distinguished folk and with rhetorical questions:

"But what kind of a King is He?" "What has he come to win?" "What new has Christ come to create in our hearts?" "Who is He?"

Eye contact is also used: research has shown that people use eye contact twice as much when they listen than when they talk (Argyle 1965; Ekman \& Friesen 1969; Argyle \& Lefebvre et al. 1974: 125-136). When you are at a distance, as in a pulpit, the preacher should make sure there is a connection. However, not many speakers do this; instead they read from their papers, maybe because there has not been enough time to rehearse the sermon. 
Second, the speaker must give the impression that he believes in his cause and that his actions are appropriate. Persuasion is possible because there is belief that the sender is reliable. The speaker appeals to ideals and persons that are important to the audience, such as Jesus, God, the Apostles and ministers of the church:

As the word of God / St. Paul / our teacher Luther says... (Suojanen 1978; 2001: 217-219.)

Third, the speaker appeals to the prestige of the church, the community or tradition:

Our church is prepared to accept even the weakest lamb, because it is the will of Jesus, the Good Shepherd.

Fourth, the speaker appeals to science and reason.

According to research, man is a herd animal. The Lord's congregation is also a tiny herd, which is hungry for the presence of a Good Shepherd.

Fifth, in mass persuasion the speaker appeals to emotions by speaking in an emphatic and altruistic code (see emotive code: Dillard \& Pfau 2002) and by taking advantage of the community's basic values, such as family, security, home, mother-child relationship:

Many of our fellow-men have experienced what unemployment means to homes, to its fathers, mothers, innocent children and single-parent families. Yet, you with a home, even a poor one, can live in peace in the middle of all the insecurities of life, even though in your heart you are afraid.

When I came to see my father in hospital and felt awkward encountering him and talking to him, my husband courageously asked him: 'Could we pray?' My father shocked me in a positive way by replying: 'Well, I guess that's the only rational thing to do in this situation.'

Sixth, the speaker in a mass uses words that arouse positive feelings and that have a high status, such as security, grace, power, life, connection. He also uses seemingly scientific or topical terms:

We do not have to worry about anything in our lives when we have the eternal God as our protection

and strength and we have a connection with His Son, Jesus Christ. Christ can strengthen our connection as family members and citizens of heaven.

Today! Today is the day of Grace. 
In this era of globalisation even Christians should network. Where does the set of values of us Christians come from nowadays? The message of prophets in the Bible was like a revolutionary talk.

If Jesus' disciples had arranged a proper strategy session, set out their targets, milestones and thought out the ways to reach them, ---

Seventh, the speaker appeals to a sense of national self-esteem, conscience and recommends The Kingdom of God, eternal life, and penance.

God's Kingdom has come close. What should we do to inherit eternal life?

The Lord offers us penance even though we do not deserve it.

And finally, the speaker uses plus and minus words, such as actually, fundamentally, in fact, a kind of, in other words. These are used to reduce or extend the content of the concepts - or even to make them opposites - according to the preferences of the speaker in a given situation (Suojanen 2001: 219).

In addition, the mass sermon has a number of philosophical, semantic and functional principles, some of which are positive, others negative from the viewpoint of the listener:

In the principle of opposites the narrative follows black-and-white binary oppositions God - man, salvation - drowning, hereafter - here, we - others, life - death. The sermon that I last heard used the following oppositions: Jesus - Satan, grace sin, to give - to take, lost treasures - lasting treasures.

Through the principle of familiarisation the speaker tries to introduce a new subject to the listener with familiar concepts: chronicates, "the tales of lives lived", is an excellent example of this, and it seems that women priests use this more often than men. Women priests also use a more pragmatic approach and they avoid doctrinal themes. One woman priest started her mass sermon on the first Advent at Tampere Cathedral to an audience of 1,500 with an animal chronicate:

When I came to be a priest here at the Cathedral congregation, I made a promise to a colleague that I will not start my sermons by telling the audience about dogs. Well, let the exception prove the rule. I have two dogs, and I never cease to wonder their sincere attachment to me. Every time I leave for work or to run an errand, they faithfully stay and guard the door, waiting for my return. Sometimes it is a long wait, which shows in puffed sofa pillows and spread-out garbage bags. But every time I come home, whether it has been five minutes or many hours, the reception is always overwhelmingly joyous. The mistress is always greeted with the same wild wiggle of a tail and with jumps of joy, meaning that again there is someone who will feed me, take me out and take care of me. - The anticipation of Christmas is here. Today, we await for our Lord, the Christ, to come among His people.

The preacher makes a dramatic transition from dogs awaiting their mistress to the congregation awaiting Christ. 
Mass sermon is a personal narrative (personal narrative e.g. Heikkinen 2002; Suojanen 2000: 91-101; Lieblich 1998; Stahl 1989; Virtanen 1982). What makes it personal are the following features:

* interpretation of Bible texts and existing sermon materials: teachings and tradition of the church, the church as an institution, religious experience and one's own understanding

* techniques of beginning and ending a text

* techniques of constructing one's own message in writing and verbally

* techniques of distancing the listener, or bringing him or the subject closer (cf. Siikala 1984)

* the ideal of the mass sermon, which is dependent on the age and generation of the preacher

* taking the context and listeners of the mass sermon into consideration.

Personal narratives, for instance sermon chronicates, have a clear function. The narrative, along with explanations of the Bible, carries the discourse forward. The narrative brings the speaker's life and his experiences closer to the listeners. It makes the speaker's intention into a concrete, easily understandable and emotionally relevant message. Personal narratives are the most human, concrete, and profane substance of the mass sermon. Especially women priests make use of bringing the listeners closer through personal narratives.

The principle of common interest refers to empathy, which is either real or fictitious.

The church is on the side of the little people here, but our primary concern is the man's immortal soul, not his earthly unemployment.

[---] it is essential that we want, ask, pray [synonymous verb paratagma] to be close to Jesus, the fountain of life, the trunk of a tree, the provider of connection and life [synonymous noun paratagma]. He, our loving Saviour, is with us at home, at work, during our free time, in sickness and in health, on good days and bad days. We can come to Him again and again, no matter how we feel. He will always receive us.

As to the authoritarian principle, the listeners are controlled by the priest's supreme leadership: who would dare to doubt the priest's word? It is easy for the preacher to appeal to his specialised knowledge with its special terminology and lose the listener's last chance to understand or ask. At university, the preacher has been trained on what a good sermon should sound like. The preacher has a solid knowledge of the sermon as a genre: that he has to preach about matters of faith in religion, which are specific for Evangelical-Lutheran faith and which sell well in a major Finnish city in the 21st century. Who would dare to question the preacher's references to the Pauline Epistles?

The preacher's trustworthy behaviour is manifested in the use of encouraging words. 
Christendom has always acted like this and survived. We know that we have the word of God as our shield.

Jesus is the tree of life, our tree of life, which is a tree of mercy and forgiveness for You, for me and for the world.

The principle of self-confidence raises the priest's own self-esteem:

In God's name we shall triumph. The situation in the world is now such that only the word and Christian love of God can help us to avoid a catastrophe; if you shall not awaken to this reality today, you are on the side of those who condemn.

As Jesus' own, we shall not be damned, but we will have eternal life in the new heaven and the new earth, the new world.

The principle of personification helps the preacher to project the main character of a religious narrative to the listener's reality. We can again use the previous animal chronicate as an example:

As dogs await their mistress, so does man await Christ.

By referring to a common interest, the preacher emphasises social virtues and why it is relevant to stick to the same congregational policy.

General humanity requires mercifulness and good will, because each of us needs help sometimes.

As Christians, we want to bear eternal fruit, to testify to Christ and to serve our fellow-men. For this, we shall need the Holy Ghost and each others' help and prayer.

When the preacher assigns blame, he uses sin, death, damnation and punishment to frighten and wake up bad conscience (cf. Dillard \& Pfau 2002):

Even in our time, there is a lot of Pharisaism, of which the Bible speaks here. I do not want to point a finger at you, my friend, but I will say it in the light of God's word: like everyone else, you are not free from sin nor of Pharisaism. (from a mass sermon of a preacher in a revivalist movement).

In this example, we find the word "sin", which is rare in mass sermons. Instead of "hell", preachers talk about "damnation" or they may leave the concept out altogether. The words "hell" and "sin" are almost completely missing from the mass sermons in this study, although $88 \%$ of Finnish clergy believe in the existence of Hell and all of them in sin (Niemelä 2004: 100). None of the women priests in my study preach about Hell, and even the men use the biblical euphemism "damnation". 93\% of Finnish priests believe in the existence of Satan, 75\% firmly, which is about the same number as those who believe in angels. It is interesting how more priests believe in the existence of the devil than in the existence of Hell. In 
Finland, more priests believe in the existence in Satan and Hell than in Sweden (Niemelä 2004: 99). These figures are from 2004. In addition, 92\% of vicars and $81 \%$ of priests believe that after death all men will awaken from the dead. Some receive eternal life, others damnation. (Niemelä 2004: 95).

Why, then, are Hell, damnation and sin not preached about? Why is the principle of assigning blame only visible in the sermons of priests who represent the revivalist movements? Are they afraid that the already decreasing numbers of churchgoers goes down even faster? In 2004, the percentage of Finnish who belonged to the Evangelical-Lutheran Church was $83.6 \%$, which was again less than the year before. Within a short time, an increasing number of people have been resigning from the church.

There is a tendency to leave out "the most gloomy" part of Christianity, namely that God can be a condemning God, and that judgment and damnation do exist (cf. Niemelä 2004: 273). This is explained by the fact that the social profile and tasks of the church have become more varied (see Kääriäinen and Niemelä et al. 2003). It is claimed that the emphasis on life before death has kept the interface between the church and its people. So the church is changing and becoming more profane along with its employees.

As to the principle of winning time, the preacher uses delay or speeding things up as wisdom by claiming that the timing is not right:

Christendom has long believed in this and acted like this, and we cannot suddenly go and change things, but the leadership of the church is already paying attention to this.

Building obstacles is based on evasion:

We in the congregation are ready to encounter man, but so few are interested in us. Man himself is the greatest obstacle to betterment and his decadence does not give much of a change to reformation.

To sum up, the most common principles in mass sermons are the principles of opposites, familiarisation, authority, trustworthiness and self-confidence, in this order. Matti Wiberg, a Finnish social scientist, has found similar philosophical principles as those that I have now outlined also in political persuasion (Wiberg 1996; 1992a: 381-382, 1992b: 171-174).

What is new in a sermon of the 21st century is that blame is no longer assigned to people, as was customary at least in some of the older revivalist movements. The sermon of women preachers, which emphasises life before death, does no longer know Hell or sin. Talking about the church's doctrines has become secondary: what is more important is the preaching of "God's mercy and forgiveness". Instead of "sin", they speak about man's "weakness", "smallness" or "shortcomings". 
Whether these semantic-functional principles are chosen depends on the cultural universe of symbols and the assigning of meaning: in other words, on the apparent and hidden functions of a particular mass sermon, the preparation of the sermon, the preacher, and his or her personal background, as well as on the listeners and their ability to put one's soul into the triangle drama, namely of sermon - preacher - speech act.

\section{MASS SERMON FROM THE VIEWPOINT OF GENRE ANALYSIS (CF. HONKO 1981: 106-138)}

The mass sermon originates in the books of the New and Old Testament. During the Reformation starting in the $1520 \mathrm{~s}$, the importance of the vernacular sermon grew, although some vernacular sermons were held even before that. The modern-day mass sermon utilises the current exegetic literature and instructions for preaching texts throughout the ecclesiastical year. The origin of the mass sermon necessitates the combination of the historical Bible text and topical events and phenomena.

The form of the mass sermon is a verbal personal narrative, epical in nature, which disseminates knowledge of the Bible to a community of believers and gives instructions for living an ethical life in a form chosen by the preacher.

The content of the mass sermon is knowledge about the crucial events in the Holy genesis, the birth and suffering of Jesus, and the salvation history of the Bible. In one word, the content of the mass sermon is cosmogonic, in which the importance of the salvation narrative warrants us to refer to it as a proto sermon. In addition to the history of the creation, the sermon narrates other "genesis events and moments", such as the birth of Jesus (Christmas mass sermons) and the suffering of Jesus (mass sermons during the Holy Week).

The function of the mass sermon is, above all, to be a role model and an example. For the believer, it is to be taken word-for-word: the mythical suffering and salvation of Christ has happened once. Salvation or waiting for salvation or some religious allegory is repeated in the Gospel and Epistle text each Sunday, for example Jesus' I am allegories: I am the Vine, the Holy Shepherd, The Bread of Life, The Way, Truth and Life. Almost 98\% of the Finnish clergy believe that the teachings and life instructions of Jesus are applicable in our day (Niemelä 2004: 83). In one word, the function of the mass sermon could be characterised as ontological: it is one explanation of the world (cf. Honko 1981: 112-115).

In principle, preachers aim to find a model for all human activities and natural phenomena from the Bible, the stories of which are often applied as such to current events. Even though all mass sermons seek a connection to the Bible, they only cover it in very small part.

The style of the mass sermon is prose, the sources of which may even include poetry. Overall, there is great variety in the style of mass sermons: one preacher 
gives a monotonous lecture, another has prepared an aesthetic performance down to stylistic typography (see appendix text: analysis of a mass sermon).

The structure of the sermon, which lasts for about 10-15 minutes, usually focuses on one topic, two at the most, which are examined by using older or newer sacred texts (the Pauline Epistles from the New Testament). Women priests prefer adaptations to modern times, using personal chronicates and direct questions, whereas older male priests use a strict, Bible-based exegesis. The mass sermon has structure models of different ages. It seems that women priests use a more modern and humane structure, which is only natural because of its shorter history: women priests were accepted in the Finnish Evangelical-Lutheran Church as late as in 1986.

\section{APPENDIX TEXT: ANALYSIS OF A MASS SERMON}

Finland, Salpausselkä Church, on Holy Thursday, 20th of May, 2004, Mass Sermon by Mrs. Riitta Kuusi, Priest for the Deaf.

The Subject of the Day: "The Gospel of Faith". Mark 16: 14-20.

Later Jesus appeared to the Eleven as they were eating: he rebuked them for their lack of faith and their stubborn refusal to believe those who had seen him after he had risen.

He said to them: "Go into all the world and preach the good news to all creation. Whoever believes and is baptised will be saved. But whoever does not believe will be condemned. And these signs will accompany those who believe: In my name they will drive out demons; they will speak in new tongues. They will pick up snakes with their hands; and when they drink deadly poison, it will not hurt them at all; they will place their hands on sick people, and they will get well." After the Lord Jesus had spoken to them, he was taken up into heaven and he sat at the right hand of God. Then the disciples went out and preached everywhere, and the Lord worked with them and confirmed his word by the signs that accompanied it.

\section{Sermon}

- Measured, weighted and found wanting! [message 1: key phrase] [long pause]

We have been told that Jesus' disciples abandoned their previous lives and answered to his call without any hesitation whatsoever. The fisherman dropped his nets on the shore, the custom official hurried from the city gates to arrange a celebration for his new employer [exegesis] [integration with modern language]

These men were not asked to present their college degrees, letters of reference or recommendations. They were good enough! [modern adaptation]

- Measured and weighted - [message 1] [long pause]

These men followed Jesus, and they were measured and weighted many-many times. "Jesus, your disciples do not fast like the disciples of John the Baptist - why? Why do they not adhere to the rules of Sabbath?" [exegesis with questions]. 


\section{Päivikki Antola}

Well, the men who followed Jesus did not quite measure up to the standards of a Jewish male. They even left behind their families, which was irresponsible behaviour for a Jew. It could be said that they selected a vagrant way of life: they did not even earn their own living, not to speak of their families [evaluation of disciples in modern language].

- Measured and weighted - [message 1] [long pause]

And even their faith was wavering [appropriate exegesis in modern terms].

Jesus had explained to his closest followers again and again what the coming of the God's Kingdom really meant. He had told about his own suffering. And when the moment arrived, those closest to Jesus slept, when he would have needed support. When a threat was looming [sentence paratagma to emphasise the message], the disciples scattered like sand in the wind [appropriate modern allegory].

When challenged, Peter, the bravest of the disciples, answered that he did not know this Jesus, not to speak of following him to the death as he had just a moment ago promised [exegesis: repetition of text].

- Measured and weighted - [message 1] [long pause]

The disciples still needed "overtime" - the unexpected appearances of the resurrected Jesus during the forty days. Even so Jesus had to rebuke his disciples for their lack of faith. [exegesis]

However, Jesus presented his mission to these men. They were given a treasure to nurture in spite of their lack of faith and incompetence. [exegesis] [transfer to this day:] We in the congregation, we in the church, have a different training for various tasks - whether those tasks belong to professionals or elected officials. ["we" - updating, allegory of the variety of ecclesiastical tasks]

\section{- Measured and weighted - [message 1] [long pause]}

It seems that we calculate the work of others better than our own even in Gospel matters. Those priests preach poorly, cantors play and make us sing the wrong kind of music, youth instructors are not able to keep the youth on the right path and church social workers are just putting in the hours... And the selected officials of the congregation are not any better, at least members of that other group (good adaptation of Bible text in modern terms).

If Jesus' disciples had arranged a proper strategy session, set out their targets, milestones and thought out the ways to reach them, they would probably have felt that the mission was impossible. Maybe it was best just to roll up the sleeves and get on with it without worrying about 'foreign languages', 'snakes' and 'poisons' that might wait ahead. [use of seemingly modern terms] [comparison: roll up the sleeves/get on with it].

- Measured and weighted - and found worthy of trust and salvation [message 2] [long pause]

That is why Jesus' disciples dared to go.

That is why we can also carry on the same mission, in our neighbourhood or far away, depending on where we are sent to. [personification principle: main characters, Jesus' disciples got salvation - maybe we will get, too] 
We do not have to stretch our neck to look at the sky. We believe that Jesus sits at the right hand of the God, but we also believe and know that he is here on earth among us every day and every moment. [allegory: to stretch our neck to look at the sky) (stress on 'we believe' and 'we believe and know'; resolution ending]

Let us confess our common faith in our Lord.

\section{Päivikki Antola: Analysis of the Sermon}

The aesthetically and even typographically sophisticated mass sermon was presented with a beautifully resonant voice (the priest is also a vocal artist), and it contained only two messages: measured and weighted (and found wanting) five times and measured and weighted - and found worthy of trust and salvation once at the end of the text.

The subject of the day was the Gospel of Faith in which Jesus tests the limits of the apostles' faith. "Whoever believes and is baptised will be saved, but whoever does not believe will be condemned." Please note the word condemned, which is used very sparingly in mass sermons, but which is referred to in Gospel text readings.

The effect of the mass sermon was based on aesthetic redundancy; the words measured and weighted were uttered with deep feeling.

Modern allegories were used in appropriate context: like sand in the wind; straining their neck; roll up the sleeves / get on with it.

The preacher used one parallel sentence paratagma: "when the moment arrived, when he would have needed support, when a threat was looming [---]"

Exegesis was presented in modern terms: "they were not asked to present any college degrees, letters of reference or recommendations"; "we in the church have various tasks"; (self irony): "when those priests preach poorly, those cantors play and make us sing the wrong kind of music, youth leaders are not able to keep the young on the right path and those church social workers are just filling in the hours [---]"

Apparently modern terminology was used: "strategy sessions", "set out their targets and initial goals", "thought out the ways to reach them", "faith was wavering", "new employer" (= Jesus).

The mass sermon was concluded with a resolution: "We believe that Jesus sits at the right hand of the God, but we believe and know that he is here on earth among us - on every day and at every moment."

The mass sermon includes a number of semantic and functional principles, which reflect the preacher's roles during the sermon:

In the authoritarian principle the listeners are controlled by the preacher's expert knowledge which forms the basis of supreme leadership. It is convenient to mix expert knowledge with special terminology and make the listeners lose even their last chance to understand and ask questions. The preacher used her authority on all parts of the sermon that dealt with exegesis. The speaker's style was eloquent and verbally brilliant, and she used her authority to present her views without hesitation.

The preacher used the principle of familiarisation often: college degrees and certificates, poor preachers, etc; seemingly modern terminology: strategy sessions, etc. 


\section{Päivikki Antola}

She acted emphatically from her very soul - not only superficially - and was 'there' during the whole sermon. She used her personality to give an extra flavour to the sermon.

The principle of self-confidence raises the priest's own self-esteem: her courageous demeanour and numerous eye contacts with the congregation prove that.

Trustworthy behaviour is manifested through religious encouraging: "We believe that Jesus sits at the right hand of the God, but we believe and know that He is here on earth among us - every day and every moment."

The principle of personification: the main characters, Jesus' disciples, were saved - maybe we all in this church can experience the same.

In the principle of opposites the preacher followed the binary opposition responsible man irresponsible man (disciple), measured and weighted - found wanting; measured and weighted - found worthy of thrust and salvation, here - there, weak in faith - filled with faith.

The preacher did not assign blame and she avoided waking up bad conscience in her listeners. Even if the text of the day has a sentence "But whoever will not believe, will be condemned", she does not mention it. The listeners are not reminded of Hell in any way. "Measured and weighted and found wanting" does not bring up Hell as a first thought. Even if $88 \%$ of Finnish clergy believe in hell, only one used the word 'damnation' in this mass sermon study. Why does the Finnish priest not preach what he believes? Why does this particular priest use an aesthetic euphemism to bring forward the subject?

Communicative repetition was used freely and there were two intimate question sentences in the sermon.

The verbal authority of the sermon was based on Mark's Gospel from the New Testament.

The defining features of the sermon were: the main phrase after the text of the day, measured and weighted (and found wanting), and the emphasis on faith as a concluding resolution.

The transitional features of the mass sermon followed the narrative transfers within Mark's Gospel.

The temporal features of the sermon reflect the two-level time division: the time of Jesus and apostles and our modern era.

Routine linguistic models reveal that this particular sermon was in our language, but also understandable to others: references to our time were so logical.

Finally, the mass sermon conveys its speaker's life and personality, the priest's social status, religious education and professional skills. The first sentences of the sermon sharpened my senses to realise that we were listening to an exceptional priest. She almost sang her words in a controlled voice and came very close to us listeners. She had a natural talent to elucidate the words and bring forward the religious message. She glowed with intellectual and aesthetic curiosity.

An average Finnish mass sermon is more often than not a written, unrehearsed, religious lecture. This particular sermon was not tied to the paper, and the preacher's vivid style overjoyed us listeners. 


\section{Summary}

The female preacher brought the subject down to earth as opposed to many of her male colleagues. The sermon explained and defended the fact that the apostles, who as human beings were considered weak, were still worthy of Jesus' mercy and thrust. The preacher used her personality and nonverbal communication as efficient media tools. She was a visiting speaker, a priest for the deaf and known to be a 'good' speaker. Her language was a combination of modern general conversational talk and religious language. In sacred language she presented herself as an authority, but was able to get close to her listeners by careful and tasteful repetition. Her pauses were thoughtful and efficient. This was a superb mass sermon.

\section{References}

Argyle, Michael 1965. Bodily Communication. London.

Argyle, Michael \& Lefebvre, L. et al. 1974. The meaning of five patterns of gaze. European Journal of Social Psychology, 4, pp. 125-136.

Baesler, E. James 1994. Religious Orientation, Persuasion and Communicator Style. Journal of Communication \& Religion, Sep. 1994, 17 (2).

Bettinghaus, Erwin P. \& Cody, Michael J. 1994. Persuasive communication. 5th ed. Forth Worth, TX: Harcourt Brace \& Company.

Dainton, Marianne 2005. Applying communication theory for professional life: a practical introduction. Thousand Oaks (Calif.): Sage Publications.

Dillard, James Price \& Pfau, Michael (eds.) 2002. The Persuasion Handbook: developments in theory and practice. Thousand Oaks (Calif.): Sage Publications. [Especially affect and persuasion: Guilt as a mechanism of persuasion.]

Ekman, Paul \& Friesen, W. V. 1969. The Repertoire of Nonverbal Behavior: Categories, origins, usage, and coding. Semiotica, 1.

Forsberg, Juhani 2001. Epäsaarna [Sermon in Parody]. J. Jolkkonen \& S. Peura et al. (eds.) Saarnan käsikirja. Helsinki: Kirjapaja, pp. 235-243.

Heikkinen, Hannu L. T. 2002. Whatever is Narrative Research? Rauno Huttunen et al. (eds.). Narrative Research, Voice of Teachers and Philosophers. Jyväskylä: SoPhi.

Honko, Lauri 1962. Geisterglaube in Ingermanland, 1. FFC, 185. Helsinki: Academica Scientiarum Fennica.

Honko, Lauri 1981 [1972]. Myytti ja riitti [Myth and Rite]. Uskontotieteen näkökulmia. 2. Helsinki: WSOY.

Klemi, Matti 1988. Sanaton kieli [A Language without Words]. Espoo: Weilin \& Göös.

Kääriäinen, Kimmo \& Niemelä, Kati et al. 2003. Moderni kirkkokansa. Suomalaisten uskonnollisuus uudella vuosituhannella [The Modern Churchpeople. Finns' Religiosity in the New Millennium]. Kirkon tutkimuskeskuksen julkaisuja, 82. Tampere: Kirkon tutkimuskeskus.

Larson, Charles U. 2001. Persuasion: reception and responsibility. 9th ed. Belmont, CA: Wadsworth /Thomson Learning. [Nonverbal messages in persuasion; persuasion in today's world; perspectives on ethics in persuasion.]

Lehtonen, Jaakko 1998. Ikuisuuskysymys: miten viesteillä vaikutetaan? Viestinnän jäljillä: näkökulmia uuden ajan ilmiöön [The Eternal Question: How to Influence via Messages? Mass Communication: Views on the Modern Phenomenon]. Helsinki, p. 153166.

Lieblich, Amia et al. 1998. Narrative Research. Reading, Analysis and Interpretation. Applied Social Research Methods Series, 47. Thousand Oaks, CA: Sage. 
Niemelä, Kati 2004. Uskonko niinkuin opetan? [Do I Believe the Way I Preach?]. Kirkon tutkimuskeskuksen julkaisuja, 85. Tampere: Kirkon tutkimuskeskus.

O'Keefe, Daniel J. 1994 [1990]. Persuasion: theory and research. 6. pr. Newbury Park, CA: Sage Publications. [Attitudes, communication, and persuasion.]

Siikala, Anna-Leena 1984. Tarina ja tulkinta. Tutkimus kansankertojista [Legend and Its Interpretation. A Study on Folk Narrators]. Helsinki: Finnish Literature Society.

Stahl, Sandra Dolby 1989. Literary Folkloristics and the Personal Narrative. Bloomington \& Indianapolis.

Stiff, James B. 1994. Persuasive communication. New York: Guilford Press. [Rhetoric and persuasion.]

Suojanen, Päivikki 1978. Saarna, saarnaaja, tilanne [Sermon, Preacher, Context]. Summary: The Spontaneous sermon: its production and context. Finnish Literature Society Publication, 343. Helsinki: Finnish Literature Society.

Suojanen, Päivikki 1988. Ylipuhujat. Viestinnän näkökulmia uskontoon ja politiikkaan [The Persuaders. Religion and Politics from the Point of View of Communication Theory]. Helsinki: Kirjapaja.

Suojanen, Päivikki 2000. The Spontaneous Sermon as a Personal Narrative. Maria Vasenkari, Pasi Enges et al. (eds.). Telling, Remembering, Interpreting, Guessing. A Festschrift for Prof. Annikki Kaivola-Bregenhoj on her 60th Birthday, 1st February 1999. Turku: Scripta Aboensia, Kultaneito III, pp. 91-101.

Suojanen, Päivikki 2001. Saarna suostuttelevana viestintänä [Sermon as Persuasive Communication]. J. Jolkkonen, S. Peura et al. (eds.). Saarnan käsikirja. Helsinki: Kirjapaja, pp. 217-234.

Wiberg, Matti 1992a. Julkisuuspelistä on leikki kaukana [Playing at Publicity is No Game]. Kanava, 20 (1992) (6), pp. 381-382.

Wiberg, Matti 1992b. Poliittinen julkisuus ei ole yksityisasia [Political Publicity is Not a Private Matter]. Kanava, 20 (1992) (3), pp. 171-174.

Wiberg, Matti 1996. Politiikan kieli on hallinnan väline: taitava poliitikko käyttää sanojen mielikuvia hyväkseen [A Politician's Language Use is a Control Tool: A Crafty Politician Uses Verbal Fantasies in His Interests]. Turun Sanomat, 3.12.1996.

Virtanen, Leea 1982. Henkilökohtainen kerronta [Personal Narrative]. Irma-Riitta Järvinen and Seppo Knuuttila (eds.). Kertomusperinne. Kirjoituksia proosaperinteen lajeista ja tutkimuksesta. Helsinki: Finnish Literature Society. 